\title{
ETIKA TERHADAP HARTA DALAM PERSPEKTIF AL-QUR'AN
}

\author{
Aan Anugrah (191320008) \\ UIN Sultan Maulana Hasanudin Banten \\ Aananugrah079@gmail.com
}

\begin{abstract}
The title of this research was distributed by some of the statements in the Qur'an about ethics against the property. On the one hand the Qur'an looked positively on treasure, on the other hand the Quran as if not condone. This research would like to find a concept of how the Qur'an against ethics against property by emphasizing the ethical discussion of acquiring property, possession and utilization of ethics of property. The type and pattern of this research was a library research which used descriptive qualitative analysis. The main object of his research was the Qur'an. Therefore, the method used was the science of tafseer. Since this research was to find a concept, the approach used was thematic tafseer. The texts relating to the subject matter of discussion. To analyze the problem, the authors used think inductively to seek the answers of various issues of life with departure from nas Qur'an towards reality (min al-Qur'an ila al-wâqi '). With this approach the authors limited themselves to things that are described by the Qur'an, including in the selection of the theme, and only use the vocabulary or term used Al Qur'an.The discussion in this paper were not directed to the type, quality or quantity of property. Instead it focused on the ethical attitude of man against the property, in which case the problem of acquiring property, possession and utilization of property. The exposure data in this discussion had several conclusions. The Qur'an mentions about wealth, it seems less condone. It does not focus on the material but it focuses on at human attitude towards wealth that makes the property into a negative. The advice of the Qur'an against the wealth not only technical problems, but rather ethical issues as moral values built in Islam.
\end{abstract}

Keywords: ethics, treasures, Qur'an

\section{Abstrak}

Judul penelitian ini dilatarbelakangi oleh beberapa pernyataan AlQur'an tentang etika terhadap harta. Di satu sisi Al-Qur'an memandang harta secara positif, di sisi lain Al-Qur'an seolah-olah tidak merestui. Penelitian ini ingin mencari konsep bagaimana pandangan Al-Qur'an terhadap etika terhadap harta dengan menekankan pembahasan etika memperoleh harta, memiliki harta dan etika pendayagunaan harta.Jenis dan corak penelitian ini adalah library yang bersifat deskriptif analisis kualitatif. Objek utama penelitiannya adalah Al-Qur'an. Oleh karena itu, metode yang digunakan adalah ilmu tafsir. Karena penelitian ini untuk menemukan konsep, pendekatan yang digunakan adalah tafsir tematik. Ayat-ayat yang berkaitan dengan pokok pembahasan. Adapun untuk 
menganalisa masalah, penulis menggunakan pikir induktif, yakni berupaya memberikan jawaban terhadap berbagai persoalan kehidupan dengan berangkat dari nas Al-Qur'an menuju realita ( min al-Qur'an ila al-wâqi'). Dengan pendekatan ini penulis membatasi diri pada hal-hal yang dijelaskan oleh Al-Qur'an, termasuk dalam pemilihan tema, dan hanya menggunakan kosa kata atau term yang digunakan Al-Qur'an.Pembahasan dalam tulisan ini tidak diarahkan pada jenis, kualitas atau kuantitas harta. Melainkan difokuskan pada sikap etis manusia terhadap harta, dalam hal masalah memperoleh harta, memiliki harta dan pendayagunaan harta. Dari pemaparan data dalam pembahasan ini, menghasilkan beberapa kesimpulan, di antaranya. Penyebutan AlQur'an terhadap kekayaan seolaholah kurang merestui, bukan ditujukan pada materinya, melain ditujukan pada sikap manusia terhadap kekayaan yang menjadikan harta menjadi negatif. Nasihat Al-Qur'an terhadap harta kekayaan bukan hanya masalah teknis, melainkan masalah etika sebagai nilai-nilai moral yang dibangun dalam Islam.

Kata Kunci : Etika, Harta, Al-Qur'an 


\section{PENDAHULUAN}

Al-Qur'an telah menyatakan dirinya sebagai kitab petunjuk (hudan) yang dapat menuntun umat manusia menuju jalan yang benar. Selain itu ia juga berfungsi sebagai pemberi penjelasan (tibya'n)terhadap segala sesuatu dan pembeda (furqa'n) antara kebenaran dan kebatilan. Al-Qur'an menyatakan bahwa Allah menciptakan alam beserta isinya sebagai sarana untuk kelangsungan hidup manusia (QS. al-Baqarah [2]: 29) dalam rangka melaksanakan tanggungjawab manusia sebagai pihak yang berpartisipasi aktif dalam meningkatkan taraf hidup manusia secara individu, kolektif atau universal.

Harta dianggap sebagai sesuatu yang lazim (tabi'î) dan urgen (d\}aruriy) berupa materiil karena dapat digunakan dalam menunjang kehidupan (wasilat al-hayah). Tidak ada salahnya seorang muslim mengumpulkan kekayaan sesuai dengan keinginannya, selama ditempuh dengan carayang halal dan sesuai dengan aturan syari'ah. ${ }^{1}$ Hal ini sebagaimana ditegaskan Allah dalam surat ali-Imrân (3): 14 sebagai berikut:

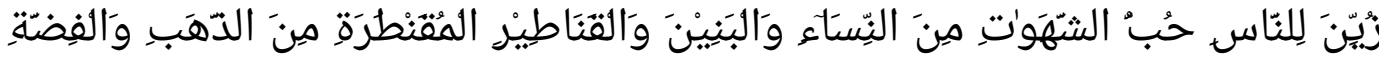

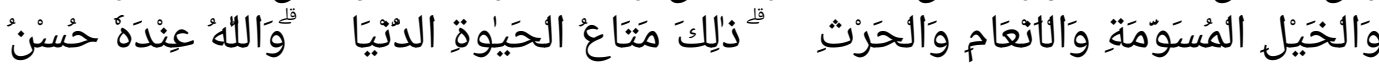

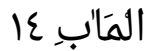

\section{Terjemah Kemenag 2002}

14. Dijadikan terasa indah dalam pandangan manusia cinta terhadap apa yang diinginkan, berupa perempuan-perempuan, anak-anak, harta benda yang bertumpuk dalam bentuk emas dan perak, kuda pilihan, hewan ternak dan sawah ladang. Itulah kesenangan hidup di dunia, dan di sisi Allah-lah tempat kembali yang baik.

Penyebutan Al-Qur'an terhadap kekayaan seolah-olah kurang merestui, bukan ditujukan pada materinya, melain ditujukan pada sikap manusia terhadap kekayaan yang menjadikan harta menjadi negatif. Nasihat Al-Qur'an terhadap harta kekayaan bukan hanya masalah teknis, melainkan masalah etika sebagai nilai-nilai moral yang dibangun dalam Islam. Al-Qur'an mengecam tindakan seseorang yang merugikan orang lain dalam masalah harta.

Penciptaan adalah dasar hak pemilikan. Pengakuan terhadap pemilikan alam ini, tidak juga pemilikan manusia. melainkan pemilikan disandarkan pada Tuhan, hanya sifatnya mengingatkan kepada manusia agar tidak bersikap angkuh, rakus, kikir terhadap harta kekayaan yang

\footnotetext{
${ }^{1}$ Yusuf al-Qardhawi, Halal dan Haram, Penj. Abu Sa'id al-Falahi dkk, (Jakarta: Robbani Press, 2000), hlm. 381.
} 
dimiliki. Al-Qur'an tidak mengecam kepemilikan manusia, melainkan mengecam sikap negatif manusia terhadap harta kekayaan. Dalam pemilikan harta kekayaan, manusia dianjurkan juga memperhatikan hakhak orang lain, yaitu dengan menyalurkan fungsi harta kekayaan yang dimilikinya kepada kaum yang lemah (yang membutuhkan), agar harta tersebut tidak berputar di antara orang kaya saja, tetapi juga kepada kaum yang membutuhkan. Dengan demikian, Pandangan Al-Qur'an terhadap kepemilikan adalah positif. Al-Qur'an memandang negatif jika kepemilikan yang ada pada kekuasaan manusia tersebut disalahgunakan.

Kajian ini dalam beberapa literatur sering dikaji, tetapi kurang begitu kritis dalam melihat fenomena yang sedang berkembang. Bahwa kajian ini bertujuan untuk memahami wawasan Al-Qur'an tentang etika manusia terhadap harta melalui isyarat dari berbagai ayat yang lebih progressif dan kontekstual, diantaranya adalah untuk mendiskripsikan, menganalisis, dan menginterpretasikan ayat-ayat AI-Qur'an mengenai etika terhadap harta.

Kajian ini sangat menarik jika dikaji dengan model baru dan gaya bahasa yang lebih responsif terhadap realita yang ada. Dalam ilmu tafsir kajian ini sering dikenal dengan metode tafsir maudhui yang sering dikaji hampir di seluruh Perguruan Tinggi Islam di Indonesia. Karena salah satu kerja tafsir maudhui adalah metode yang berupaya menetapkan satu topik tertentu dengan jalan menghimpun seluruh atau sebagian ayat-ayat dari berbagai surah yang berbicara tentang topik tersebut untuk kemudian dikaitkan satu dengan yang lainnya sehingga pada akhirnya diambil kesimpulan menyeluruh tentang masalah tersebut menurut pandangan AlQur'an. Diharapkan tulisan singkat ini bisa membawa pemahaman baru bagi para pengkaji kajian tafsir, lebih-lebih dalam berinteraksi pada zaman sekarang. Oleh karena itu akan dijelaskan terlebih dahulu mengenai hal itu.

\section{URGENSI ETIKA}

Persoalan moralitas dalam hubungannya dengan interaksi antar manusia merupakan persoalan utama dan berperan penting pada zaman ini. Beberapa persoalan krusial yang muncul, antara lain adalah bagaimana manusia harus bersikap menghadapi perkembangan teknologi yang demikian pesat pada saat ini. Semua persoalan tersebut merupakan masalah moralitas dunia yang perlu dipikirkan dengan segera. Kenyataan yang ada pada saat ini bahwa kemajuan ilmu pengetahuan dan teknologi khususnya kemajuan teknologi informasi telah berkembang lebih cepat dari pada pemahaman terhadap nilai-nilai. Pengabaian terhadap nilai-nilai, justru menyebabkan manusia kehilangan kendali bahkan mengalami depresi, karena krisis moral dan tidak ada upaya membangun etika spiritual untuk mengimbangi lajuanya perkembangan dan peranan teknologi serta ilmu pengetahuan. Perhatian terhadap persoalan nilai-nilai sekaligus tanggap terhadap persoalan-persoalan baru yang berkembang tersebut akan membantu memberikan jawaban yang sangat diperlukan untuk menjawab krisis di dunia modern saat ini.

Sekarang tampaknya sepakat bahwa sains harus dilandasi etika. 
Etika adalah persoalan tata tertib, cara hidup yang paling baik, apa yang harus dan jangan dilakukan. Sampai di sini kita memasuki filsafat moral, tanpa etika dan moral akhirnya sains terkatung-katung dalam relativisme. Lebih celaka lagi, karena sains dan penghayatan manusia tentang etika tidak berkembang serasi. Kita sudah merekayasa dalam sains dan teknologi, tetapi masih merayap dalam etika. Ini yang disebut Wiliiam F. Obburn sebagai kesenjangan budaya. Masyarakat kehilangan keseimbangan. Akibatnya manusia diantarkan ke situasi yang mencemaskan. Bukan saja terjadi peluruhan sosial, tetapi juga peluruhan kepribadian. Ironisnya, di negara yang ber sains tinggi, terjadi kemunduran ruhani dan kehancuran mental. Porak porandanya lembaga keluarga, kehilangan pegangan hidup, terjadi revolusi seksual, kejahatan adalah beberapa sisi nyata kehidupan modern. ${ }^{2}$

Peran etika mendapatkan tempatnya dengan munculnya persoalanpersoalan di atas. Sumbangan yang dapat diberikan etika pada saat ini adalah untuk menyediadan orientasi. Walaupun tidak setiap orang memerlukan orientasi, karena kebanyakan orang sudah beretika, namun sebagian orang tidak begitu saja mempercayakan diri pada pandangan lingkungan di sekelilingnya dan merasakan kebutuhan suatu orientasi kritis di bidang moral. Setidaknya terdapat empat alasan perlunya etika pada zaman sekarang ini. $^{3}$

Pertama, individu hidup dalam masyarakat yang semakin pluralistik, termasuk di dalamnya di bidang moralitas. Dalam masyarakat yang berbeda seringkali terdapat nilai atau norma yang berbeda. Setiap hari individu berinteraksi dengan orang-orang yang berlatar belakang suku, daerah dan agama yang berbeda-beda. Individu berhadapan dengan pandangan moral yang beragam dan sering kali saling bertentangan satu dengan yang lain. Individu sering kebingungan untuk mengikuti moral yang benar yang harus diikuti. Panduan moral yang berasal dari orang tua, moralitas yang ditawarkan melalui pergaulan di masyarakat yang plural tersebut. Pluralitas moral ini dirasakan lebih dasyat pada saat ini, ketika hidup di era komunikasi. Melalui media komunikasi kejadian-kejadian di belahan dunia dengan seketika dapat sampai ke rumah.

Secara historis, etika sebagai bagian dari pemikiran filsafat berkembang bersamaan dengan keambrukan tatanan moral di lingkungan kebudayaan Yunani +2500 tahun yang lalu. Pandanganpandangan lama yang berkaitan dengan baik dan buruk tidak dipercayai masyarakat, maka para filosof mempertanyakan kembali norma-norma dasar bagi perilaku manusia. Situasi tersebut berulang pada era sekarang ini. Perbedaannya dengan zaman Yunani adalah pada saat ini yang dipersoalkan bukan hanya pertanyaan yang berkaitan dengan kewajiban dan tidak merupakan kewajiban. Melainkan manakah norma-norma untuk menentukan apa yang harus dianggap sebagai kewajiban. Sedangkan pada saat ini norma-norma

\footnotetext{
${ }^{2}$ Jaluluddin Rahmat, Islam Alternatif, (Bandung: Mizan, 1999), hlm. 159

${ }^{3}$ Franz Magnis Suseno, Etika Dasar: Masdalah-masalah Pokok Filsafat Moral, (Yogyakarta:Kanisius, 1987), hlm. 15.
} 
moral itu sendiri yang dipersoalkan. Misalnya dalam bidang etika seksual, hubungan anak dan orang tuanya, kewajiban terhadap negara, etika sopan santun dan pergaulan. Untuk mencapai suatu pendirian dalam pergolakan pandangan-pandangan di bidang moral ini maka refleksi kritis tentang etika diperlukan.

Kedua, pada saat ini individu berada dalam pusaran transformasi masyarakat yang berlangsung sangat cepat. Gelombang modernisasi telah meramah ke segala penjuru tanah air, hingga masuk ke pelosokpelosok desa. Bahkan ke tempat yang sebelumnya tidak dapat dijamah. Melalui kemajuan teknologi semua tempat dapat dipantau. Tidak terdapat sisa celah pada dimensi kehidupan yang tidak terkena dampak modernisasi ini. Kehidupan dalam kota-kota sekarang ini berbeda dari kota -kota seribu tahun sebelumnya. Perbedaannya bukan hanya belum terdapat kendaraan bermotor, plastik, alat-alat elektronika, media masa, melainkan cara berfikir manusia berubah secara radikal. Berubahnya cara berfikir manusia, menjadikan berkembangnya rasionalisme, individualisme, nasionalisme, pluralisme, materialism religious serta adanya sistem pendidikan modern telah mengubah lingkungan budaya dan rohani secara hakiki di dunia ini, termasuk di Indonesia. Dalam transformasi yang begitu cepat dibidang ekonomi, sosial, intelektual telah meluluhkan nilai-nilai budaya yang tradisional.

Dalam menghadapi situasi ini etika sangat dibutuhkan manusia guna untuk membantu agar manusia jangan sampai kehilangan orientasi, akhirnya manusia dapat membedakan antara moralitas yang hakiki yang tidak boleh berubah dan pemahaman-pemahaman yang boleh berubah. Dengan demikian manusia tetap sanggup untuk mengambil sikap-sikap dalam kehidupannya dan sanggup untuk mempertanggungjawabkan atas perbuatannya.

Ketiga, bahwa proses perubahan sosial budaya dan moral saat ini telah dipergunakan oleh pihakpihak yang tidak bertanggungjawab untuk memancing dalam air keruh. Orang-orang tersebut menawarkan edeologiedeologinya sebagai obat penyelamat. Dengan adanya etika ini manusia sanggup untuk mengahadapi edeologi-edeologi yang telah menyimpang itu dengan kritis dan obyektif dalam membentuk penilaian sendiri, agar manusia tidak mudah terpancing dan terpengaruh terhadap edeologi dan ajaran yang dibawanya. Etika dapat membantu manusia agar jangan naïf atau ekstrim dalam ajaran yang kelihatan menyilaukan ini. Manusia jangan cepat-cepat mengikuti segala pandangan yang baru muncul, namun demikian manusia jangan juga menolak niali-nilai yang baru muncul tersebut hanya karena hal baru dan belum terbiasa melakukannya.

Keempat, etika juga diperlukan oleh kaum agamawan, karena dapat membantu agamawan untuk memantapkan dasar keimanan dan kepercayaannya, sekaligus berpartisipasi dan tidak menutup diri dalam 
dimensi kehidupan masyarakat yang sedang berubah itu. ${ }^{4}$

Karakter khusus etika sebagian besar bergantung kepada konsepnya mengenai manusia dalam hubungannya dengan tuhan, dengan dirinya sendiri, alam dan masyarakat. Islam menunjuk manusia bebas bertanggung jawab untuk mewujudkan karakternya, dia harus dibimbing dengan tujuan sadar sepenuhnya untuk mengarahkan kebijaksanaan secara seimbang. Oleh karena itu, manusia harus disesuaikan dengan lingkungannya, dengan alam luas. Sehingga manusia tidak dapat hanyut tanpa arah dalam lingkungannya. Pada waktu yang sama,perilaku egoisnya berkurang karena Islam menghendaki manusia agar peka terhadap lingkungannya, demi perbaikan dan tanggung jawab yang telah dipegang sepenuhnya. ${ }^{5}$

\section{PENGERTIAN HARTA}

Harta merupakan salah satu tema penting yang mengitari manusia, karena ia menyangkut sarana pokok kehidupan yang primer. Untuk mengetahui hakikat harta, terlebih dahulu haruslah mengetahui makna atau pengertian harta itu sendiri. Dalam beberapa kamus (Bahasa Indonesia, Inggris, Arab) serta ensiklopedia pada umumnya memberikan definisi yang hampir sama, walaupun dengan penekanan redaksi yang berbeda-beda. Dalam bahasa Indonesia, diantaranya dalam Kamus Lengkap Bahasa Indonesia tertera bahwa Harta adalah barang-barang, uang dan sebagainya yang menjadi kekayaan dan milik seseorang. ${ }^{6}$

Dalam bahasa arab secara etimologis kata "Harta" diterjemahkan dengan kata al-mal / ملالlyang bentuk jamaknya adalah al-amwal / ألموال. Al-Mal berarti condong dan berpaling dari suatu posisi keposisi yang lain.

Pengertian lain berasal dari kata kerja ma>la-yami>lu-mailan يميل - مال - ( ) ميال berarti cenderung kepada sesuatu dan membelakangi sesuatu yang lain. ${ }^{7}$ Secara terminologi kata "mâl" sering didefinisikan sebagai segala sesuatu yang dimiliki manusia baik secara individual maupun kolektif, seperti dirham, dinar, emas, perak, gandum, hewan, baju dan lain-lain. ${ }^{8}$

Harta juga bermakna sesuatu yang diinginkan manusia berdasarkan tabiatnya, baik manusia itu akan memberikannya atau menyimpannya. Sesuatu yang tidak dapat disimpan tidak dapat disebut sebagai harta. Menurut Hanafiah manfaat dan milik tidak disebut harta. Harta adalah sesuatu zat ('ain) yang berharga bersifat materi yang berputar di antara manusia.

\footnotetext{
${ }^{4}$ Suseno, Etika Dasar, hlm. 16.

${ }^{5}$ Nawab Haider Naqvi, Ethics and Economics, Terj. Asep Hikmat dkk, (Bandung: Mizan, 1985), hlm. 89.

${ }^{6}$ Purwodarminto, Kamus Besar Bahasa Indonesia, (Jakarta: Balai Pustaka, 1991), hlm. 342

${ }^{7}$ M. Jamaluddin Ibnu Mukarram Ibnu Manzhur, Lisa>n al-'Arab, (Beirut: Dar al-Fikr,), juz 13, hlm. 159.

${ }^{8}$ Azharuddin Lathif, Fiqh Muamalat, (Jakarta: UIN Jakarta Press, 2005), hlm. 22. Lihat juga Ibnu Manzhur, Lisa>n al- 'Arab..., juz 13, hlm. 158.
} 
Fuqaha kontemporer, mendefinisikan harta secara umum dan luas yaitu, segala sesuatu yang dapat menjadi hak milik seseorang dan dapat diambil manfaatnya. Misalnya, Mustafa az-Zarqa, mengartikan mâl berarti segala sesuatu yang bernilai dan bersifat harta atau segala sesuatu yang bernilai material dikalangan masyarakat. Yang dimaksud segala sesuatu berarti semua benda baik berupa yang nayata maupun yang abstrak termasuk hak-hak merupakan pengertian benda. ${ }^{9}$

Dari definisi di atas, dapat diambil kesimpulan bahwa harta adalah sesuatu yang dikumpulkan dan dimiliki, baik secara individu maupun secara kolektif, berupa kekayaan yang mempunyai nilai dan manfaat baik berupa materi maupun non materi.

\section{STATUS DAN KEDUDUKAN HARTA}

Harta merupakan salah satu kebutuhan pokok manusia dalam menunjang kehidupan di dunia ini. Di dalam Al-Qur'an, harta memiliki status dan kedudukan diantaranya adalah:

\section{Sebagai Amanah}

Harta yang selama ini dicari, dimiliki dan dimanfaatkan, manusia tidak mampu mengadakan benda dari tiada menjadi ada, sehingga manusia diberi mandat sebagai pembawa amanat dari Allah Swt. Manusia hanya diberi amanah untuk mengelola dan memanfaatkannya sesuai dengan ketentuan Allah sebagai Sang Pemilik. Selain itu, Islam menegaskan bahwa kekayaan dan harta yang berada ditangan manusia bukan saja berasal dari Allah, akan tetapi milik Allah. Hal ini telah ditegaskan dalam surat al-Hadîd (57): 7 sebagai berikut: )

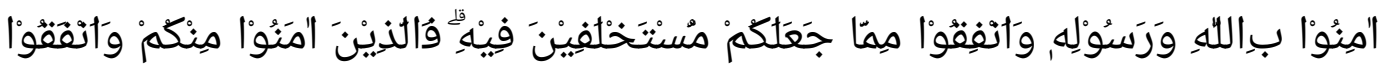

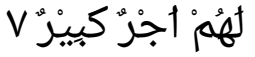

\section{Terjemah Kemenag 2002}

7. Berimanlah kamu kepada Allah dan Rasul-Nya dan infakkanlah (di jalan Allah) sebagian dari harta yang Dia telah menjadikan kamu sebagai penguasanya (amanah). Maka orang-orang yang beriman di antara kamu dan menginfakkan (hartanya di jalan Allah) memperoleh pahala yang besar.

Kata mustakhlafîna dari ayat di atas menurut az-Zamakhsyarî: ${ }^{10}$ "Bahwa harta yang ada pada tangan kalian adalah harta Allah yang diciptakan dan dikembangkannya untuk kalian. Allah telah memberikan dan mengizinkan harta tersebut untuk kalian nikmati. Allah menjadikan sebagian kalian khalifah-khalifah yang mampu untuk mengelola harta. Karena itu, harta tersebut bukanlah milik kalian. Posisi kalian terhadap harta itu hanyalah

\footnotetext{
${ }^{9}$ Fathurrahman Djamil, Hukum Ekonomi Islam, (Jakarta: Sinar Grafika, 2013), hlm. 174.

${ }^{10}$ Abul Qasim Mahmud bin Umar al-Khawarizmi az-Zamakhsyari. Lahir 27 Rajab 467 H, sebuah perkampungan besar di kawasan Khawarizm (Turkistan), salah satu karyanya yang terkenal adalah Tafsir al-Kasyaf. Manna' Khalil alQattan, Maba>hith fi> 'Ulu>m alQur'a>n, (Mansyurat al-Ashr al-Hadis, 1990), hlm. 388.
} 
sebagai wakil dan pemegang amanat. Oleh karena itu, infakkanlah harta itu pada hak-hak Allah. Ringankanlah tanganmu untuk menginfakkannya, sebagaimana seseorang menginfakkan harta orang lain dengan ringan.

\section{Harta Sebagai Perhiasan Hidup}

Manusia mempunyai kecenderungan untuk memiliki, menguasai dan menikmati harta QS. Ali-Imrân (3): 14. Di dalam Al-Qur'an, harta disebut sebagai perhiasan hidup, harta sering menyebabkan keangkuhan, kesombongan, serta kebanggaan QS. al-Alaq (96): 6-7. Harta sebagai perhiasan hidup yang menunjuk kepada fungsinya sebagai perhiasan, baik pakaian maupun perhiasan yang dikenakan pada tubuh untuk memperindah penampilan. Sebgaimana dijelaskan dalam surat al-'A'râf (7): 31: )

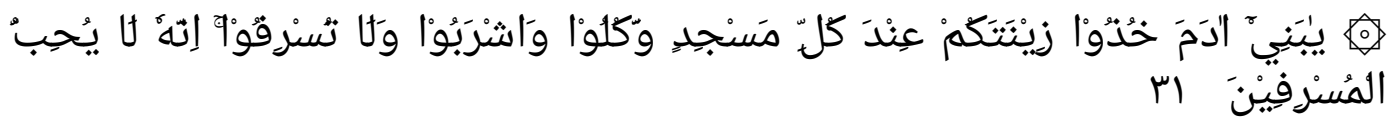

Terjemah Kemenag 2002

31. Wahai anak cucu Adam! Pakailah pakaianmu yang bagus pada setiap (memasuki) masjid, makan dan minumlah, tetapi jangan berlebihan. Sungguh, Allah tidak menyukai orang yang berlebih-lebihan.

Ayat di atas tidak hanya memerintahkan untuk berhias, akan tetapi memberi peringatan agar jangan sampai berhias melebihi yang dibutuhkan oleh tubuh. Karena kalau sudah berlebihan maka unsur keindahannya menjadi hilang. Apapun bentuknya kalau sudah melampaui batas termasuk pakaian dan perhiasan dapat menghilangkan nilai estetika dari perhiasan itu sendiri. Bahkan orang yang banyak memiliki perhiasan dikhawatirkan tidak lagi berorientasi kepada keindahan melainkan akan menjadi pamer, memalingkan pandangan dan perhatian orang banyak kepada dirinya yang pada akhirnya timbul kesombongan. Hal ini sangat dilarang oleh Allah.

\section{Harta Sebagai Fitnah / Ujian Keimanan}

Harta bukanlah sesuatu yang buruk dan bukan pula siksaan, sebagaimana anggapan sebagian manusia. Harta juga bukan ukuran bagi ketinggian derajat pemiliknya, atau tanda keutamaan dan kesalehan, sebagaimana anggapan sebagian yang lainnya. Akan tetapi, harta merupakan nikmat yang diberikan oleh Allah kepada manusia, yang tujuannya adalah untuk menguji pemiliknya, apakah manusia mau bersyukur atau bahkan mengkufurinya. Karena itu, Allah menyebut harta sebagai fitnah, yaitu ujian dan cobaan. Hal ini telah ditegaskan dalam surat al-Anfâl (8): 28 sebagai berikut: )

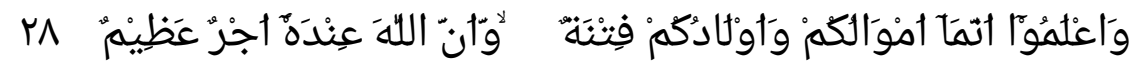

\footnotetext{
${ }^{11}$ Abu al-Qasim Mahmud bin Umar bin Ahmad Zamakhsyarî?, Tafsi>r al-Kashsha>f, ( Beirut: Dar al-Kitâb al-'Arabi, 1407 H), juz 3, hlm. 200.
} 
Terjemah Kemenag 2002

28. Dan ketahuilah bahwa hartamu dan anak-anakmu itu hanyalah sebagai cobaan dan sesungguhnya di sisi Allah ada pahala yang besar.

Ibnu Asur dalam tafsirnya memberikan pengertian "fitnah" yaitu kegoncangan hati serta kebingungan. Sebab akibat adanya situasi yang tidak sejalan dengan suasana yang menghadapi situasi itu. Sedang Wahbah az-Zuhailiy memberikan makna fitnah itu dalam tiga dampak yang akan dimunculkan. Diantaranya:

1. Dapat mendorong seseorang untuk berbuat yang haram.

2. Enggan menunaikan hak-hak Allah.

3. Dapat melakukan perbuatan tercela dan dosa.

4. Harta Sebagai Bekal Ibadah

Seyogianya harta yang dimiliki seseorang itu digunakan untuk ibadah dan muamalah dalam bentuk melaksanakan perintah Allah melalui kegiatan zakat QS. at-Taubah (9): 103, berinfak QS. al-Baqarah (2): 267, sedekah QS. al-Baqarah (2): 276. Sebagai contoh dalam firman Allah surat atTaubah (9): 103 sebagai berikut: )

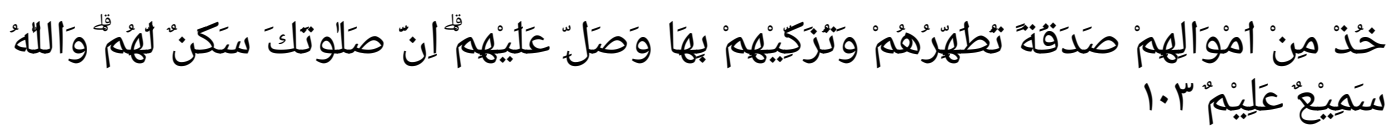

Terjemah Kemenag 2002

103. Ambillah zakat dari harta mereka, guna membersihkan dan menyucikan mereka, dan berdoalah untuk mereka. Sesungguhnya doamu itu (menumbuhkan) ketenteraman jiwa bagi mereka. Allah Maha Mendengar, Maha Mengetahui.

Dari beberapa ayat di atas menjelaskan yang intinya bahwa harta itu bisa berfungsi sebagai bekal ibadah kepada Allah, salah satunya berupa pengeluaran zakat setiap tahunnya, berinfaq setiap saat maupun bersedekah kepada kaum duafa' dalam waktu yang tidak terikat dan terbatas.

\section{ETIKA MENCARI HARTA}

Penjelasan tentang etika mencari harta dalam bagian ini adalah usaha manusia untuk menemukan, mendapatkan harta dalam rangka memenuhi hajat dan kebutuhan hidupnya. Untuk mendapatkan harta tersebut di antaranya adalah berusaha dan bekerja dengan sungguhsungguh.

Bekerja adalah merupakan fitrah dan sekaligus merupakan identitas manusia, sehingga bekerja yang didasarkan dan didorong oleh semangat iman, bukan saja menunjukkan identitas sebagai seorang muslim, akan tetapi hal tersebut sekaligus mengangkat martabat dirinya sebagai seorang khalifah di muka bumi ini (QS. al-Baqarah [2]: 30). Manusia diberi 
mandat untuk memakmurkan, mengelola, mengatur, menata, menguasai, memelihara dan melestarikan bumi ini, sebagai sarana dan prasarana kehidupan untuk mencari rezeki (QS. Hûd [11]: 61)

Dalam Al-Qur'an terdapat beberapa ayat yang menganjurkan untuk berusaha dan bekerja dengan sungguh-sungguh (QS. al-Ankabût [29]:69). Salah satu contoh firman Allah dalam surat az-Zumar (39): 39

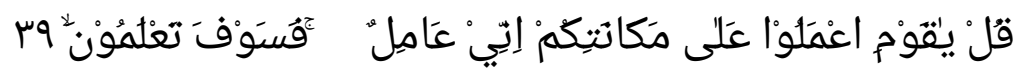

Terjemah Kemenag 2002

39. Katakanlah (Muhammad), "Wahai kaumku! Berbuatlah menurut kedudukanmu, aku pun berbuat (demikian). Kelak kamu akan mengetahui,

Ada beberapa hal yang perlu diperhatikan dalam mencari harta, di antaranya:

\section{Jangan Bertransaksi Harta dengan Cara Batil}

Allah memberikan tuntunan kepada mereka dalam bertransaksi dan halhal yang bermanfaat dengan jalan jual beli semua macam muamalah yang berhubungan dengan pekerjaan, sehingga kehidupan manusia bisa berdiri dengan tegak dan dapat berjalan dengan baik dan produktif.

Ketika dalam transaksi itu mengandung unsur pertentangan, baik disebabkan karena adanya sesuatu yang tidak diketahui pada barang yang diperjual belikan atau karena adanya unsur penipuan yang dapat memicu terjadinya pertentangan antara kedua belah pihak, maka transaksi tersebut dilarang. Sebagaimana ditegaskan dalam surat al-Baqarah (2): 188 sebagai berikut:

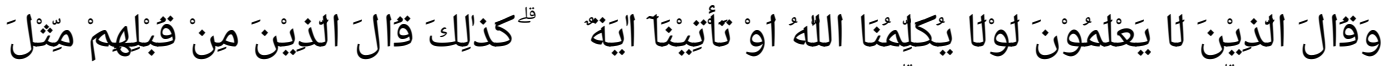

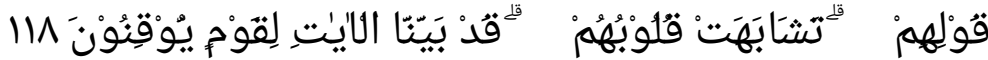

Terjemah Kemenag 2002

118. Dan orang-orang yang tidak mengetahui berkata, "Mengapa Allah tidak berbicara dengan kita atau datang tanda-tanda (kekuasaan-Nya) kepada kita?" Demikian pula orang-orang yang sebelum mereka telah berkata seperti ucapan mereka itu. Hati mereka serupa. Sesungguhnya telah Kami jelaskan tanda-tanda (kekuasaan Kami) kepada orang-orang yang yakin.

Ayat di atas menggambarkan dua kejahatan yang terjadi dalam hubungannya dalam mencari harta, yaitu kejahatan secara yuridis dan kejahatan secara etis. Kejahatan secara yuridis adalah melanggar hak orang lain yang dilindungi secara paksa. Pelanggaran ini disimbolkan dengan kata memakan. Kejahatan ini pelakunya dituntut aktif dan reaktif. Adapun kejahatan secara etis atau dikatakan juga kejahatan terselubung, adalah kejahatan yang dilakukan oleh orang yang membeck up legal formal tersebut. Kejahatan tipe ini pelakunya bersifat pasif, ia hanya berada di balik layar. 


\section{Menyempurnakan Timbangan atau Takaran dalam Transaksi}

Al-Qur'an memerintahkan sikap etis dalam mencari kekayaan yang memalului transaksi. Salah satu sikap etis dalam bertransaksi untuk mencari harta atau kekayaan yang dilegimitasi oleh Al-Qur'an adalah menyempurnakan timbangan, takaran dan ukuran lainnya sesuai dengan kesepakatan. Untuk mencapai nilai etis dalam pencarian kekayaan, AlQur'an telah mengecam kecurangan dalam takaran dan ukuran sekaligus memerintahkan untuk menyempurnakannya.

Kecaman Al-Qur'an terhadap kecurangan didasarkan pada firman Allah dalam surat al-Muthaffifin (83): 1-3 sebagai berikut: )

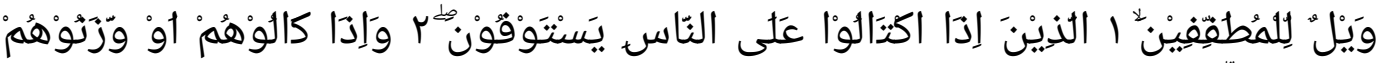

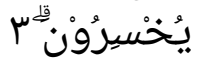

Terjemah Kemenag 2002

1. Celakalah bagi orang-orang yang curang (dalam menakar dan menimbang)!

2. (Yaitu) orang-orang yang apabila menerima takaran dari orang lain mereka minta dicukupkan,

3. dan apabila mereka menakar atau menimbang (untuk orang lain), mereka mengurangi.

Al-Qur'an mengecam kecurangan dalam bertransaksi karena bukan saja merugikan orang lain, akan tetapi merugikan pelakunya juga. Pelaku ekonomi ketika melihat kecurangan yang dilakukan mitranya, ia akan mengalihkan kemitraannya kepada orang lain. Hilangnya kemitraan adalah awal dari kehancuran dalam dunia ekonomi. Dalam interaksi dibidang ekonomi sifat kejujuran melintasi semua sentimen, mulai dari kekerabatan, kesukuan sampai keagamaan. Orang lebih senang bermitra dengan orang yang bukan keluarga, suku bahkan agamanya yang memiliki loyalitas kejujuran yang tinggi, dari pada bermitra dengan keluarga, suku, serta agama yang tidak memiliki sifat amanah. ${ }^{12}$

\section{Larangan Bersistem Riba}

Secara bahasa, kata "riba" berarti bertumbuh, menambah, atau berlebih. ${ }^{13}$ Sementara menurut terminologi fiqih, riba adalah tambahan pada modal yang dipinjamkan yang harus ditanggung oleh orang yang berhutang sampai jangka waktu peminjaman dengan prosentase yang telah ditetapkan oleh yang memberi hutang. ${ }^{14}$ Dari pengertian tersebut, riba yang dikecam Al-Qur'an adalah riba yang berkaitan dengan sistem kegiatan ekonomi, sistem tersebut akan berakhir pada hasil.

Dalam Al-Qur'an, kata riba disebut sebanyak delapan kali yang terdapat

\footnotetext{
${ }^{12}$ M. Quraish Shihab, Tafsir al-Mishbah, (Jakarta: Lentera Hati, 2002), vol. 15, hlm. 142

${ }^{13}$ M. Dawam Rahardjo, Ensiklopedi Al-Qur'an), (Jakarta: Paramadina, 2002), hlm. 603.

${ }^{14}$ al-Qaradhawi, Halal Haram, hlm. 308.
} 
dalam empat surat, yaitu (QS. ar-Rûm [30]: 39), (QS. al-Baqarah [2]: 275, 276, 278,), (QS. ali-Imrân [3]: 130), dan (QS. an-Nisâ' (4): 161). ${ }^{15}$

Para ulama sepakat tentang pengharaman riba, berdasarkan beberapa ayat yang telah dikemukakan di atas. Salah satu perbincangan yang terjadi adalah dalam mengasumsikan bahwa riba hanya dianalogikan dengan bunga yang identik dengan pertambahan modal, maka logika orang musyrik yang menyamakan antara jual beli dengan riba cukup beralasan, karena yang nampak dari dua kegiatan tersebut adalah pertambahan modal. Tetapi logika tersebut dijawab oleh Tuhan dengan redaksi yang berbeda (QS. al-Baqarah [2]: 275), bahwa jual beli yang bertujuan mencari tambahan modal diperbolehkan, sementara riba dilarang.

Tindakan riba yang dikecam oleh Al-Qur'an dalam QS. an-Nisâ' [4]: 161, disamakan dengan makan harta orang lain dengan ilegal. Dengan demikian, kecaman terhadap riba bukan masalah pertambahan modal, tetapi masalah kejahatan kekayaan yang berpusat pada proses pengumpulannya.

\section{ETIKA KEPEMILIKAN HARTA}

Dalam bahasa Indonesia, kepemilikan kadang diistilahkan dengan kata "hak", atau dengan kata "milik" atau dirangkai dengan "hak milik" yang berarti benar, kewenangan, kekuasaan untuk berbuat sesuatu, kekuasaan yang benar atas sesuatu atau untuk menuntut sesuatu, derajat atau martabat. $^{16}$

Dalam bahasa arab kata milik sering diungkapkan dengan istilah al-milk

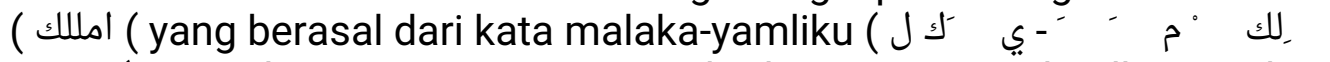
${ }^{-}$( yang berarti penguasaan terhadap sesuatu, al-milk juga berarti sesuatu yang dimiliki. ${ }^{17}$

Pengertian hak secara etimologi adalah ketetapan dan kepastian. sedangkan secara terminologi fikih, hak adalah suatu hukum yang telah ditetapkan secara syara'. Sedangkan milik secara etimologi adalah penguasaan terhadap sesuatu, dan secara terminologi adalah kekhususan terhadap pemilik suatu barang menurut syara' untuk bertindak secara bebas bertujuan mengambil manfaat suatu barang selama tidak ada halangan syara'. ${ }^{18}$ Apabila seseorang telah memiliki suatu benda yang sah menurut syara', orang tersebut bebas bertindak terhadap harta, baik akan dijual atau akan digadaikan, baik dia sendiri maupun dengan perantaraan orang lain. Pada prinsipnya atas dasar milkiyah (pemilikan) seseorang mempunyai keistimewaan berupa kebebasan dalam membelanjakannya selama tidak ada halangan tertentu yang diakui oleh syara'.

Halangan syara' yang dimaksud adalah yang membatasi kebebasan

\footnotetext{
${ }^{15}$ Muhammad Fuad Abdu al-Bâqî , al-Mu'jam al-Mufahras li Alfa $>$ z al-Qur'a>n, (Beirut: Dar al-Hadis, 2007) , hlm. 368.

${ }^{16}$ Hutomo, Kamus Besar Bahasa Indonesia, (Surabaya: Mitra Pelajar, 2005), hlm. 177.

${ }^{17}$ Luis Ma'lûf, al-Munjid fi> al-Lughah wa al-A'la>m, (Birut: Dar al-Masyriq, 1986), hal.774.

${ }^{18}$ Mardani, Fiqih Ekonomi Islam, (Jakarta: Kencana, 2012), hlm. 66.
} 
pemilik dalam membelanjakan sesuatu yang menjadi haknya ada dua macam: pertama, halangan yang disebabkan karena pemilik dipandang tidak cakap secara hukum, seperti anak kecil, atau karena adanya cacat mental atau karena alasan failit. Kedua, halangan yang dimaksudkan untuk melindungi hak orang lain, seperti yang berlaku pada harta bersama, dan halangan dimaksudkan untuk melindungi kepentingan orang lain atau kepentingan masyarakat umum". ${ }^{19}$

Dengan demikian, pandangan Al-Qur'an terhadap kepemilikan adalah positif. Al-Qur'an memandang negatif jika pemilikan yang ada pada kekuasaan manusia tersebut disalahgunakan. Dalam konsep Islam, Allah adalah pemilik mutlak atas segala sesuatu yang ada di alam raya ini. Dia menciptakan bumi dengan segala isinya termasuk manusia (QS. Nûh [71]: 17). Setelah Allah menciptakan bumi, lalu kemudian Allah menyediakan fasilitas yang dibutuhkan manusia untuk memakmurkan dan menjaga eksistensinya dalam kehidupan di dunia ini. ${ }^{20}$

Pemilikan harta atau kekayaan yang merupakan setiap manusia untuk memenuhi kebutuhan dasar harus diperhatikan nilai-nilai etisnya. Nilai etis dalam pemilikan adalah tersalurnya fungsi kekayaan untuk pemenuhan hajat hidup orang banyak dengan memperhatikan tindakan berikut:

\section{Tidak Boleh Menimbun Harta Kekayaan}

Harta harus difungsikan, karena kalau ditumpuk dan tidak difungsikan maka jumlah modal kerja yang mestinya tersedia menjadi berkurang, hal ini dapat mengurangi kesejahteraan yang didambakan Al-Qur'an. Semua kekayaan yang dimiliki seseorang harus digunakan untuk memenuhi kebutuhan pemilik dan keluarganya, sedang yang berlebih harus diupayakan sedemikian rupa sehingga terjadi sirkulasi harta yang dapat menyentuh masyarakat banyak. ${ }^{21}$

Meskipun Islam memberikan kebebasan kepada setiap orang di dalam melakukan jual beli dan melakukan persaingan yang sehat, namun Islam sangat menentang sifat egois dan ambisi pribadi yang mendorong sebagian orang memperkaya diri sendiri meskipun dari hasil menimbun dan mengekploitasi bahan baku yang menjadi kebutuhan rakyat. Oleh karena itu Nabi Saw melarang menimbun dengan menggunakan ungkapan yang sangat keras.

\section{"Saudagar diberi rezeki, sedang penimbun dilaknat. (HR. Ibnu Majah)"22}

Dari sini apabila pemusatan kekayaan pada satu atau dua kelompok orang saja, maka akan berpengaruh pada pengurangan sirkulasi fungsi kekayaan, baik di kalangan individu maupun kelompok (QS. al-Hasyr [59]:

\footnotetext{
${ }^{19}$ Azharuddin Lathif, Fiqh Muamalat,(Jakarta: UIN Jakarta Press, 2005), hlm. 49.

${ }^{20}$ Djamil, Hukum ekonomi, hlm. 193.

${ }^{21}$ M. Quraish Shihab, Membumikan Al-Qur'an, (Jakarta: Lentera Hati, 2011), Jilid 2, hlm. 392.

${ }^{22}$ Abu Abdillah Ahmad Ibin Muhammad Ibn Hanbal bin Hilal, Musnad Imam Ahmad bin Hanbal, (Beirut: Muassasah ar-Risâlah, 2001), juz. 8, hlm. 485.
} 
7). Apalagi jika pemusatan tersebut dilakukan secara sistimatis yang hanya menguntungkan individu atau kelompok tertentu. Orang yang melakukan ini di ancam oleh Allah (QS. at-Taubah [9]: 34), (QS. alHumazah [104]: 1-2.

\section{Bersikap Wajar}

Dalam menjelaskan kewajaran dalam pemilikan, Al-Qur'an telah mengecam sikap berlebih-lebihan dan pemborosan di dalam berbagai ayat. Menurut al-Qaradawi sikap berlebih-lebihan dan hidup mewah bukanlah dua istilah bersinonim yang salah satunya cukup mewakili yang lainnya. Akan tetapi, di antara keduanya ada relevansi keumuman dan kekhususan masing-masing. Sikap hidup mewah biasanya diringi sikap berlebihlebihan. Sedangkan sikap berlebih-lebihan belum tentu diiringi sikap mewah.

Kesederhanaan dalam kepemilikan, Al-Qur'an menjelaskan dan memberikan batas kutub ekstrim yang sama-sama dikecam, yaitu antara sikap kikir dan sikap boros. Kecaman terhadap kedua sikap tersebut agar kekayaan berfungsi sebagaimana mestinya. Sikap kikir adalah pengurangan dan penyempitan fungsi harta dari yang sewajarnya. Sikap boros adalah penghamburan fungsi dan nilai harta dari yang tidak pada fungsi dan tempat yang sewajarnya. Keduanya mengurangi dan membatasi fungsi harta bagi orang yang membutuhkan.

\section{Larangan Bersifat Angkuh}

Sikap angkuh pada hakikatnya bertolak belakang dengan fitrah kemakhlukan. Hal ini ditandai dengan ketergantungan kehidupan manusia kepada Allah. Sangat tidak pantas apabila sikap ini disandang oleh manusia. Di dalam berbagai ayat, Al-Qur'an menjelaskan bahwa manusia akan bertindak semena-mena ketika ia memandang dirinya serba berkecukupan. Dalam kondisi ini, manusia juga melupakan akhir perjalanan hidupnya setelah mengingkari pemberi kecukupannya QS. alAlaq [96]: 6-8. Sikap kecukupan kadang-kadang mempengaruhi manusia untuk bersikap sombong dan berbangga dengan pemilikan yang ada padanya. Sebagaimana ditegaskan dalam surat al-Hadîd (57): 23-24 sebagai berikut:

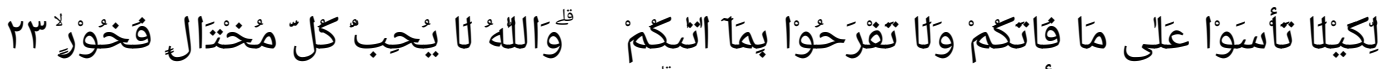

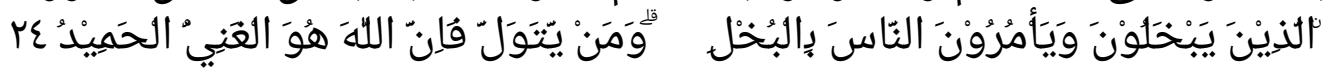

Terjemah Kemenag 2002

23. Agar kamu tidak bersedih hati terhadap apa yang luput dari kamu, dan jangan pula terlalu gembira terhadap apa yang diberikan-Nya kepadamu. Dan Allah tidak menyukai setiap orang yang sombong dan membanggakan diri,

24. yaitu orang-orang yang kikir dan menyuruh orang lain berbuat kikir. Barangsiapa berpaling (dari perintah-perintah Allah), maka sesungguhnya Allah, Dia Mahakaya, Maha Terpuji. 


\section{Memperhatikan Hak-hak Orang Lain.}

Setelah Al-Qur'an mengecam kesombongan dan keangkuhan yang disebabkan oleh sifat kikir, dalam kesempatan lain Al-Qur'an juga mengingatkan kepada mereka yang di tangannya ada kekuasaan (kepemilikan), bahwa di dalam kekayaannya terdapat hak orang lain yang harus ditunaikan. Pemilik hak tersebut adalah mereka yang membutuhkan kehadiran fungsi kekayaan yang disebut oleh Al-Qur'an dengan istilah assâil. Sebagaimana disebutkan dalam surat adzDzâriyât (51): 19 sebagai berikut:

"Dan pada harta-harta mereka ada hak untuk orang miskin yang meminta dan orang miskin yang tidak mendapat bagian.

Di dalam Al-Qur'an kata al-sâil yang menunjuk pada obyek materi untuk memenuhi kebutuhan hidup QS. al-Baqarah [2]: 177, QS. al-Ma'ârij [70]: 2425, QS. ad-Duhâ [93]: 10, dalam berbagai konteks dikaitkan dengan kebajikan yang seharusnya dilakukan oleh orang yang beriman. Dalam konteks ini, kebajikan dikaitkan dengan pembelanjaan harta kepada komunitas-komunitas tertentu. Di antaranya adalah mereka yang meminta -minta sebagai tanda kesempurnaan kebajikan (QS. al-Baqarah [2]: 277). Kelompok al-sâil yang dibela oleh Al-Qur'an sebagai pemilik hak, karena mereka bersikap bahwa demi menjaga harga diri dan martabatnya di hadapan Tuhan, mereka malu mengungkapkan permintaannya di hadapan manusia (QS. adz-Dzâriyât [51]: 19), (QS. al-Ma'ârij [70]: 25). Terhadap kelompok ini, Al-Qur'an mengetuk perasaan pemilik harta agar memperhatikan nasib mereka yang sering diabaikan oleh hartawan.

Demikian pesan Al-Qur'an kepada pemilik dan penguasa harta. Dengan kekuasaan dan kepemilikan kekayaan, mereka dilarang melupakan hak orang lain yang berkepentingan terhadap manfaat kekayaan tersebut. Segala bentuk tindakan yang berefek pada gangguan dan halangan terhadap orang lain untuk memperoleh manfaat kekayaan, dikecam keras oleh Al-Qur'an.

\section{ETIKA PENDAYAGUNAAN HARTA}

Dalam pandangan tauhid, Allah menciptakan alam agar didayagunakan untuk kemakmuran kehidupan (QS. Hûd [11]: 61). Banyak ayat yang menegaskan bahwa Tuhan menciptakan bumi, langit, dan segala apa yang ada di dalamnya adalah sebagai jaminan hidup dan modal kehidupan bagi manusia, diantaranya adalah QS. al-Baqarah [2]: 22, QS. Ibrâhim [14]: 32, QS. al-Hijr [15]: 20, QS. an-Nahl [16]: 12, QS. al-Isrâ' [17]: 66, QS. Lukmân [31]: 20.

Salah satu anugerah Allah kepada manusia adalah diberikannya kebebasan untuk memanfaatkan kekayaan dalam rangka pemenuhan kebutuhan hidupnya, batas minimal dalam pendayagunaan tersebut adalah tercukupinya kebutuhan pokok. Sedangkan batas maksimal adalah ketika konsumsi bukan lagi merupakan kebutuhan melainkan pemborosan 
dan penghamburan.

Mendayagunakan harta di sini maksudnya adalah bagaimana manusia menyikapi harta yang telah ada ditangannya. Ketika harta telah didapatkan, kemudian manusia dituntut untuk bersikap bijaksana dalam mendayagunakan harta tersebut. Islam telah memberikan tuntunan bagaimana mengelola agar harta tersebut memberikan kemaslahatan bagi pemilik dan manusia lainnya.

Tentu saja aktivitas membelanjakan harta ini tidak lepas dari konsep ibadah, sebagaimana yang telah dijelaskan dalam surat al-Baqarah (2): 261 sebagai berikut:

"Perumpamaan (nafkah yang dikeluarkan oleh) orang-orang yang menafkahkan hartanya di jalan Allah adalah serupa dengan sebutir benih yang menumbuhkan tujuh bulir, pada tiap-tiap bulir seratus biji. Allah melipat gandakan (ganjaran) bagi siapa yang Dia kehendaki. dan Allah Maha Luas (karunia-Nya) lagi Maha mengetahui."

Bahwa Islam memberikan aturan-aturan yang diharapkan mampu mendorong beredarnya harta agar tidak berada di pihak-pihak tertentu saja. Dorongan Islam dalam hal itu baik dalam bentuk yang sunnah maupun yang wajib. Diantaranya adalah: zakat, infaq, sadaqah, qurban.

\section{KESIMPULAN}

Al-Qur'an telah mengatur semua tingkah laku etis manusia, di dalam berhubungan dengan Allah, sesamanya, maupun terhadap alam, sehingga terjalin keharmonisan. Harta adalah segala sesuatu yang dimiliki berupa meteriil yang dapat digunakan dalam menunjang kehidupan manusia, karena dengan adanya harta manusia bisa terpenuhi semua kebutuhan pokoknya demi kelangsungan hidupnya sampai waktu tertentu, tanpa keberadaan harta justru akan menimbulkan bencana besar berupa kelaparan yang pada akhirnya akan berujung pada kematian.

Bahwa Al-Qur'an memandang harta kekayaan secara positif, tingkah laku manusia yang membuat harta kekayaan itu imagnya negatif. Penyebutan Al-Qur'an terhadap harta kurang merestui, bukan ditujukan kepada nilai materinya, akan tetapi sikap mausia terhadap harta yang mengakibatkan harta itu ternodai. Bahwa Al-Qur'an telah menjelaskan mengenai manusia dalam berinteraksi dengan harta, di dalam hal etika manusia dalam memperoleh, memelihara dan melestarikannya. Allah adalah pemilik mutlak seluruh apa yang ada di alam raya ini dan segala apa yang ada di dalamnya, namun sarana dan prasarana tersebut, diperuntukkan untuk kepentingan dan kelangsungan hidup manusia.

Cara memperoleh harta kekayaan, Al-Qur'an menganjurkan untuk bekerja dengan sungguhsungguh, tanpa mengenal putus asa dan juga tidak boleh menempuh usaha terlarang, yaitu memakan harta dengan cara -cara yang tidak dibenarkan, memakan hasil riba, menipu, suap menyuap.

Pendayagunaan harta kekayaan yang dimiliki untuk kepentingan 
sosial melalui cara-cara yang telah disebutkan di atas, bukan berarti ingin merampas hak orang kaya dan bukan mendidik orang lemah untuk meminta-minta, tetapi semua itu dilakukan demi pengabdiannya kepada Allah.

\section{DAFTAR PUSTAKA}

Anshari, Jamaluddin Muhammad Ibnu Mukarram Ibnu Manzhur al-. Lisa>n al-'Arab. Beirut: Dar al-Fikr. t.th.

Baqi, Muhammad Fuad Abdu al-. Al-Mu'jam al-Muhfaras li Alfa>zh alQur'a>n al-Kari>m. Beirut: Dar al-Hadis. 2007.

Djamil, Fathurrahman. Hukum Ekonomi Islam. Jakarta: Sinar Grafika. 2013.

Hutomo. Kamus Besar Bahasa Indonesia. Surabaya: Mitra Pelajar. 2005.

Ibnu Hanbal bin Hilal, Abu Abdillah Ahmad Ibin Muhammad. Musnad Imam Ahmad bin Hanbal. Beirut: Muassasah ar-Risalah. 2001.

Lathif, Azharuddin. Fiqh Muamalat. Jakarta: UIN Jakarta Press. 2005.

Ma'luf, Luis. Al-Munjid fi> al-Lughah wa al-'A'la>m. Beirut: Dar al-Masyriq. 1986.

Mardani. Fiqih Ekonomi Islam. Jakarta: Kencana. 2012.

Naqvi, Nawab Haider. Ethics and Economics, Terj. Asep Hikmat dkk. Bandung: Mizan. 1985.

Purwodarminto. Kamus Besar Bahasa Indonesia. Jakarta: Balai Pustaka. 1991.

Qardhawi, Yusuf al-. Halal dan Haram, Penj. Abu Sa'id al-Falahi dkk. Jakarta: Robbani Press.1997.

Rahardjo, M. Dawam. Ensiklopedi Al-Qur'an. Jakarta: Paramadina. 2002.

Rahman, Fazlur. Doktrin Ekonomi Islam. Yogyakarta: Dana Bhakti Prima Yasa. 2002.

Rahmat, Jaluluddin. Islam Alternatif. Bandung: Mizan. 1999.

Rifa'i, Muhammad Nasib al-. Taisir al-'Aliyyu al-Qadir li Ikhtis\}ar Tafsir Ibni Kathir, terj. Shihabuddin. Jakarta: Gema Insani. 1998.

Shihab, M. Quraish. Tafsir al-Mishbah. Jakarta: Lentera Hati. 2002.

Membumikan Al-Qur'an. Jakarta: Lentera Hati. 2011. Suseno, Franz Magnis. Etika Dasar: Masdalah-masalah Pokok Filsafat Moral. Yogyakarta:Kanisius. 1987. Zamakhsyari, Abu al-Qasim Mahmud bin Umar bin Ahmad al-. Tafsir al-Kashshaf. Beirut: Da>r alKitab al-'Arabiy. $1407 \mathrm{H}$ 